\title{
Effect of Fertilizer Source on Nitrate Leaching and St. Augustinegrass Turfgrass Quality
}

\author{
Subhrajit K. Saha and Laurie E. Trenholm ${ }^{1}$ \\ Environmental Horticulture Department, University of Florida, P.O. Box \\ 110675, Gainesville, FL 32611
}

\section{J. Bryan Unruh \\ West Florida Research and Education Center, University of Florida, Jay, FL 32565}

Additional index words. Stenotaphrum secundatum, ornamental plants, multispectral reflectance, visual quality, tissue nutrient concentration, nitrate, leaching

\begin{abstract}
As a result of the coexistence of turfgrass and ornamentals in traditional landscapes, it is often impractical to separate fertilization and irrigation management among species. Furthermore, limited information is available on effects of turfgrass fertilizer on ornamental plants and vice versa. This research studied effects of two quickrelease fertilizers (QRF) and one slow-release fertilizer (SRF) on quality and growth of turfgrass and ornamental plants and nutrient leaching. 'Floratam' St. Augustinegrass (Stenotaphrum secundatum Walt. Kuntze) was compared with a mix of common Florida ornamentals, including canna (Canna generalis L.H. Bailey), nandina (Nandina domestica Thunb.), ligustrum (Ligustrum japonicum Thunb.), and allamanda (Allamanda cathartica L.). All plants were grown in 300-L plastic pots in Arredondo fine sand. Less nitrate $\left(\mathrm{NO}_{3}{ }^{-}\right)$was leached from turfgrass than from ornamentals and more $\mathrm{NO}_{3}{ }^{-}$ leached from QRF 16N-1.7P-6.6K than from SRF 8N-1.7P-9.9K. Quick-release fertilizers produced higher plant quality. This controlled environment research provides preliminary data on which in situ research may be modeled. Further research is required to verify how nutrient release rate affects turfgrass and ornamental quality and nitrate leaching in an urban landscape.
\end{abstract}

St. Augustinegrass is a widely used warmseason turfgrass for home lawns throughout the south. St. Augustinegrass prefers moderate cultural practices (Cisar et al., 1992) with a fertility requirement of 10 to $30 \mathrm{~g} \cdot \mathrm{m}^{-2} \cdot \mathrm{yr}^{-1}$ $\mathrm{N}$ (Trenholm et al., 2000a). In residential areas, lawn fertilization is often cited as a major contributor to nonpoint source pollution, which may lead to elevated levels of $\mathrm{NO}_{3}{ }^{-}$in groundwaters. Petrovic (1990) demonstrated that $\mathrm{NO}_{3}{ }^{-}$has the potential to leach through soils and contaminate groundwater if not properly applied, although other research has shown that properly applied fertilizer is assimilated by the grass (Erickson et al., 2001; Snyder et al., 1984). Proper fertilizer management, including appropriate rates, sources, application timing, and proper irrigation after fertilizing, have all been shown to influence $\mathrm{NO}_{3}{ }^{-}$leaching (Gross et al., 1990).

Controlled-release fertilizers have been shown to reduce fertilizer leaching from turfgrass (Killian et al., 1966). Brown et al. (1982) observed nitrate losses of $8.6 \%$ to

Received for publication 21 Aug. 2006. Accepted for publication 13 Dec. 2006.

${ }^{1}$ To whom reprint requests should be addressed; e-mail letr@ufl.edu. fertilizer sources, 2) to evaluate $\mathrm{NO}_{3}{ }^{-}$leaching from different fertilizer sources, and 3 ) to compare nutrient leaching of turfgrass versus ornamentals.

\section{Materials and Methods}

The research was performed in a climatecontrolled greenhouse at the G.C. Horn Memorial Turfgrass Field Laboratory at the University of Florida in Gainesville. 'Floratam' St. Augustinegrass and a combination of ornamentals that included Canna generalis L. var. 'Brandywine', Ligustrum japonicum Thunb. var. 'Lake Tresca', Nandina domestica Thunb. var. 'Harbor Dwarf', and Allamanda cathartica L. were established in large plastic pots in May 2002. Pots measured $0.8 \mathrm{~m}$ in diameter by $0.4-\mathrm{m}$ tall with a volume of 300 L. Mature St. Augustinegrass sod was harvested from the research field and planted to cover the entire surface area of the pots. Ornamental plants grown in 2.8-L containers were acquired from a retail nursery and one of each species was planted in each ornamental treatment pot.

Pots were placed on reinforced metal tables in the greenhouse. Five centimeters of gravel was placed at the bottom of the pots, and a mesh cloth was placed over the gravel to retain the media. Pots were filled with Arredondo fine sand (loamy, siliceous, hypothermic, Grossarenic Paleudalt). Turfgrass treatments received $2.5 \mathrm{~g} \cdot \mathrm{m}^{-2} \mathrm{~N}, 0.28 \mathrm{~g} \cdot \mathrm{m}^{-2}$ $\mathrm{P}$, and $1.0 \mathrm{~g} \cdot \mathrm{m}^{-2} \mathrm{~K}$ at $14 \mathrm{~d}$ after planting and were then allowed to establish for 6 weeks before treatments began.

There were three fertilizer treatments: quick-release fertilizer (QRF) $16 \mathrm{~N}-1.7 \mathrm{P}-$ 6.6K (Lesco, Cleveland, $\mathrm{OH}$ ) (ammonium sulfate, concentrated superphosphate, and potassium chloride), QRF $15 \mathrm{~N}-0 \mathrm{P}-12.5 \mathrm{~K}$ (Lesco) (ammonium sulfate and potassium chloride), and a slow-release fertilizer (SRF) $8 \mathrm{~N}-1.7 \mathrm{P}-9.9 \mathrm{~K}$ (polymer-coated sulfurcoated urea, ammonium phosphate, and polymer-coated potassium sulfate). Fertilizer treatments were applied six times at 2-month intervals (17 July 2002, 19 Sept. 2002, 20 Nov. 2002, 17 Jan. 2003, 18 Mar. 2003, and 21 May 2003) at a rate of $4.9 \mathrm{~g} \cdot \mathrm{m}^{-2} \cdot \mathrm{yr}^{-1} \mathrm{~N}$ to both turfgrass and ornamentals. Each of these 2-month periods is referred to as one fertilizer cycle (FC).

Leachate was collected three times during each fertilizer cycle, at 2, 4, and 8 weeks after fertilizer application. To facilitate leachate collection, a hole was drilled into one side of the pot. A 13-mm diameter polyethylene tube was attached to the pot to allow leachate to drain into a dark 19-L plastic bucket. Samples were submitted to the Analytical Research Laboratory in Gainesville for $\mathrm{NO}_{3}{ }^{-}$ analysis. Throughout the study, the volume of total leachate collected was measured. Results are presented based on both nutrient concentration in leached water $\left(\mathrm{mg} \cdot \mathrm{L}^{-1}\right)$ and total nitrate content leached $(\mathrm{mg})$ over the FC. Nitrate content was calculated by multiplying nitrate concentration with the corresponding leachate volume. 
Turfgrass visual quality ratings were taken weekly on a scale of 1 to 9 , with 9 being best, 1 being worst, and 6 being minimally acceptable turfgrass quality. Multispectral reflectance (MSR) readings were taken three times during each FC on turfgrass treatments-at weeks $1-2,3-5$, and 7-8 using a Cropscan model MSR 16R (CROPSCAN, Inc., Rochester, MN). Reflectance was measured at specific wavelengths: 450,550 , 660, 694, 710, 760, 835, and $930 \mathrm{~nm}$. Some important MSR indices are normalized difference vegetation index, measured as $\left(\mathrm{R}_{930}-\right.$ $\left.\mathrm{R}_{660}\right) /\left(\mathrm{R}_{930}+\mathrm{R}_{660}\right)$, and Stress-1, measured as $R_{710} / R_{760}$.

To determine thatch accumulation, three $25.5-\mathrm{cm}^{2}$ cores were collected from each turfgrass pot during the first week of May 2003. Cores were $7.6 \mathrm{~cm}$ deep. Shoots and roots were removed from the collected plugs, dried for $48 \mathrm{~h}$ at $72{ }^{\circ} \mathrm{C}$, and weighed to measure the thatch. Dried thatch was ashed in a muffle furnace $\left(450{ }^{\circ} \mathrm{C}\right.$ for $\left.5 \mathrm{~h}\right)$ and organic material weight was determined.

Recently matured leaf tissue samples were collected from both turfgrass and ornamentals in July and Nov. 2002 and Mar. and July 2003. Samples were dried, ground, and analyzed for nutrient concentration $(\mathrm{N}, \mathrm{P}, \mathrm{K}, \mathrm{Ca}, \mathrm{Mg}, \mathrm{Fe}$, $\mathrm{Zn}, \mathrm{Cu}$, and $\mathrm{Mn}$ ). Analysis of $\mathrm{N}$ was done by total Kjeldahl nitrogen procedure and the remaining elements were analyzed with Spectro Ciros ICP (SPECTRO Analytical Instruments GMBH \& Co. KG, Kleve, Germany). At termination of the experiment, shoots and roots from each pot were harvested and dried to constant weight at $75{ }^{\circ} \mathrm{C}$. Roots of ornamental plants were excavated and washed but were not separated by plant species as a result of the intermingling of roots.

Turfgrass was mowed every week with scissors to maintain a height of $9 \mathrm{~cm}$ and clippings were removed. Cypress mulch was applied to ornamentals at a thickness of $2.5 \mathrm{~cm}$. A micronutrient blend (STEP HiMag; The Scotts Co., Marysville, OH) was applied at a rate of $6.7 \mathrm{~g} \cdot \mathrm{m}^{-2}$ during Sept. 2002 to both turfgrass and ornamentals. To control a minor infestation of armyworm (Spodoptera spp.) in turfgrass, $8 \%$ bifenthrin was applied at a rate of $4 \mathrm{~g} \cdot \mathrm{L}^{-2}$. Ligustrum were treated with a $2 \%$ insecticidal oil during November to control scale (Hemiberlesia lataniae) infestation. Irrigation was applied uniformly to both turfgrass and ornamentals as needed over the course of the year.

Experimental design was a randomized complete block with four replications. Data were analyzed with the SAS analytical program (SAS Institute, 2003) to determine treatment differences at $P=0.05$ and means were separated with Fisher's least significant difference.

\section{Results and Discussion}

Visual quality, color, and density. Higher visual scores in the first 2 weeks after fertilizer applications were obtained with QRF treatments (Table 1). By 3 weeks after treatment application, QRF $15 \mathrm{~N}-0 \mathrm{P}-12.5 \mathrm{~K}-$
Table 1. Turfgrass visual quality in response to fertilizer sources.

\begin{tabular}{llccc}
\hline Weeks & \multicolumn{1}{c}{ Fertilizer } & Quality & Color & Density \\
\hline 1 WAT & QRF 15N-0P-12.5K & $7.1 \mathrm{a}^{2}$ & $7.2 \mathrm{a}$ & $7.1 \mathrm{a}$ \\
& QRF 16N-1.7P-6.6K & $7.0 \mathrm{a}$ & $7.1 \mathrm{a}$ & $7.0 \mathrm{a}$ \\
& SRF 8N-1.7P-9.9K & $6.6 \mathrm{~b}$ & $6.6 \mathrm{~b}$ & $6.6 \mathrm{~b}$ \\
& ANOVA & $<0.0001$ & 0.005 & 0.0002 \\
& & & & \\
& QRF 15N-0P-12.5K & $7.5 \mathrm{a}$ & $7.5 \mathrm{a}$ & $7.4 \mathrm{a}$ \\
& QRF 16N-1.7P-6.6K & $7.4 \mathrm{a}$ & $7.4 \mathrm{a}$ & $7.3 \mathrm{a}$ \\
& SRF 8N-1.7P-9.9K & $7.0 \mathrm{~b}$ & $7.0 \mathrm{~b}$ & $7.0 \mathrm{~b}$ \\
& ANOVA & 0.002 & $<0.0001$ & 0.0014 \\
& & & & \\
& QRF 15N-0P-12.5K & $7.0 \mathrm{a}$ & $7.0 \mathrm{a}$ & $6.9 \mathrm{a}$ \\
& QRF 16N-1.7P-6.6K & $6.9 \mathrm{ab}$ & $6.9 \mathrm{a}$ & $6.8 \mathrm{a}$ \\
& SRF 8N-1.7P-9.9K & $6.7 \mathrm{~b}$ & $6.7 \mathrm{a}$ & $6.7 \mathrm{a}$ \\
& ANOVA & 0.03 & 0.12 & 0.12 \\
\hline
\end{tabular}

${ }^{2}$ Means followed by the same letter do not differ significantly at $P=0.05$. Visual scores are based on a scale from 1 to 9 , with 9 being best, 1 being worst, and 6 being minimally acceptable turfgrass quality. Means are averaged over six fertilizer cycles (FC).

$\mathrm{WAT}=$ weeks after treatment; $\mathrm{QRF}=$ quick-release fertilizer; $\mathrm{SRF}=$ slow-release fertilizer; ANOVA $=$ analysis of variance.

Table 2. Turfgrass thatch, shoot and root weight in response to fertilizer treatments. ${ }^{\mathrm{z}}$

\begin{tabular}{lccc}
\hline Fertilizer & Thatch dry wt $\left(\mathrm{g} \cdot \mathrm{cm}^{-2}\right)$ & Shoot dry wt $(\mathrm{g})$ & Root dry wt $(\mathrm{g})$ \\
\hline QRF 15N-0P-12.5K & $0.150 \mathrm{ay}$ & $1082.46 \mathrm{a}$ & $161.83 \mathrm{a}$ \\
QRF 16N-1.7P-6.6K & $0.126 \mathrm{~b}$ & $1069.96 \mathrm{a}$ & $168.25 \mathrm{a}$ \\
SRF 8N-1.7P-9.9K & $0.108 \mathrm{c}$ & $867.59 \mathrm{~b}$ & $140.68 \mathrm{a}$ \\
ANOVA & 0.0011 & 0.048 & NS \\
\hline
\end{tabular}

${ }^{\mathrm{z}}$ Weights taken at termination of the experiment.

${ }^{y}$ Means followed by the same letter do not differ significantly at $P=0.05$.

$\mathrm{QRF}=$ quick-release fertilizer; $\mathrm{SRF}=$ slow-release fertilizer; ANOVA = analysis of variance; $\mathrm{NS}=$ not significant.

treated turfgrass had better quality than SRF $8 \mathrm{~N}-1.7 \mathrm{P}-9.9 \mathrm{~K}$-treated turfgrass, but no differences were found in color or density attributable to fertilizer. Beyond 3 weeks after fertilizer application, no differences in color, quality, or density were noted (data not shown). Faster initial release of $\mathrm{N}$ from the QRFs produced better turfgrass quality, color, and density. Similar results were noted in bermudagrass [Cynodon dactylon (L). Pers. $\times$ C. transvaalensis Burtt Davy] ultradwarf cultivars (Hollingsworth et al., 2005).

Thatch, shoot, and root growth. Thatch accumulation was $19 \%$ and $39 \%$ greater in turfgrass treated with $15 \mathrm{~N}-0 \mathrm{P}-12.5 \mathrm{~K}$ than in turfgrass treated with $16 \mathrm{~N}-1.7 \mathrm{P}-6.6 \mathrm{~K}$ and SRF $8 \mathrm{~N}-1.7 \mathrm{P}-9.9 \mathrm{~K}$, respectively (Table 2 ). Greater shoot mass $(24 \%$ and $23 \%$, respectively) was observed in QRF $15 \mathrm{~N}-0 \mathrm{P}-12.5 \mathrm{~K}$ and $16 \mathrm{~N}-1.7 \mathrm{P}-6.6 \mathrm{~K}$-treated turfgrass compared with SRF (Table 2) as a result of the faster rate of $\mathrm{N}$ release from the QRFs. No differences were found in root mass attributable to fertilizer treatments.

Nitrate leaching by concentration $\left(m g \cdot L^{-1}\right)$. Averaged across fertilizer treatments, more $\mathrm{NO}_{3}{ }^{-}$leached from ornamentals than from turfgrass at 15 and $60 \mathrm{~d}$ after treatment (DAT) and when sampling dates were averaged (Fig. 1). Differences in $\mathrm{NO}_{3}{ }^{-}$ leaching were found between turfgrass and ornamentals in FC 2 (Sept. to Nov. 2002), FC 4 (Jan. to Mar. 2003), and FC 5 (Mar. to May 2003) (Fig. 2). In a study in south Florida, Erickson et al. (2001) observed that a greater amount of $\mathrm{NO}_{3}^{-}$leached from ornamentals $\left(1.46 \mathrm{mg} \cdot \mathrm{L}^{-2}\right)$ in comparison with turfgrass

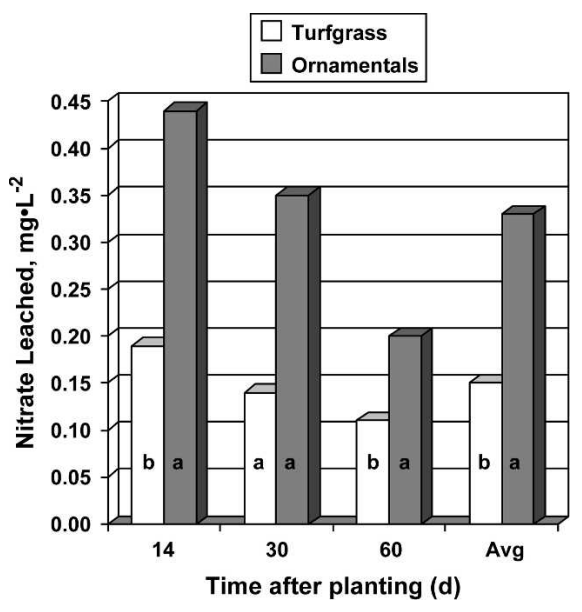

Fig. 1. Nitrate $\left(\mathrm{mg} \cdot \mathrm{L}^{-2}\right)$ leaching of turfgrass and ornamentals. Ornamentals included Canna generalis L. var. Brandywine, Ligustrum japonicum Thunb. var. Lake Tresca, Nandina domestica Thunb. var. Harbor Dwarf, and Allamanda cathartica L. Bars with the same letter are not different at $P=0.05$. Means are averaged over six fertilizer cycles.

(less than $0.2 \mathrm{mg} \cdot \mathrm{L}^{-2}$ ) and that more than $30 \%$ of the applied $\mathrm{N}$ was leached from the ornamentals and less than $2 \%$ from the turfgrass.

Averaged over both plant treatments, the most $\mathrm{NO}_{3}{ }^{-}$was leached from QRF $16 \mathrm{~N}-1.7 \mathrm{P}-6.6 \mathrm{~K}$ and the least from SRF 8N-1.7P-19.9K (Fig. 3). Quick-release fertilizer $16 \mathrm{~N}-1.7 \mathrm{P}-6.6 \mathrm{~K}$ leached less $\mathrm{NO}_{3}^{-}$from turfgrass than from ornamentals at 15 and 


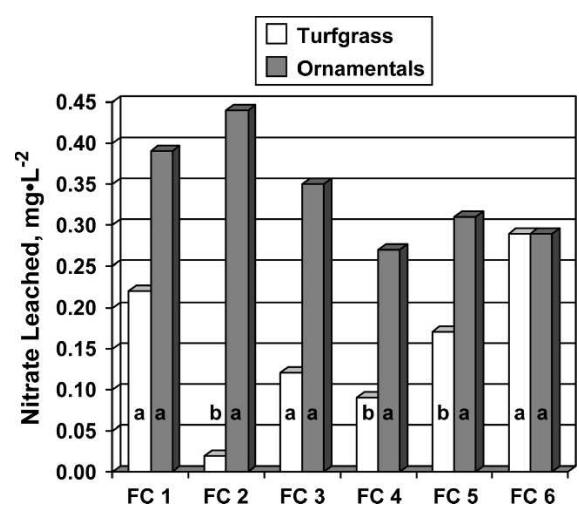

Fig. 2. Nitrate $\left(\mathrm{mg} \cdot \mathrm{L}^{-2}\right)$ leaching from turfgrass and ornamentals in six fertilizer cycles. Ornamentals included Canna generalis L. var. Brandywine, Ligustrum japonicum Thunb. var. Lake Tresca, Nandina domestica Thunb. var. Harbor Dwarf, and Allamanda cathartica L. Bars with the same letter are not different at $P=0.05$. Means are average of three leachate collections per fertilizer cycle.

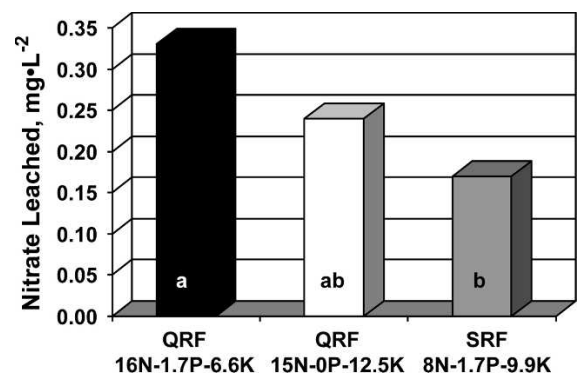

Fig. 3. Nitrate leaching $\left(\mathrm{mg} \cdot \mathrm{L}^{-2}\right)$ from different fertilizers averaged from both turfgrass and ornamentals. Ornamentals included Canna generalis L. var. Brandywine, Ligustrum japonicum Thunb. var. Lake Tresca, Nandina domestica Thunb. var. Harbor Dwarf, and Allamanda cathartica L. Bars with the same letter are not different at $P=0.05$. Means are averaged over six fertilizer cycles.

60 DAT and when averaged overall sampling dates (Table 3). There were no differences in leaching between plant types with QRF $15 \mathrm{~N}-0 \mathrm{P}-12.5 \mathrm{~K}$ or SRF $8 \mathrm{~N}-1.7 \mathrm{P}-9.9 \mathrm{~K}$.

Total nitrate leaching by volume $(\mathrm{mg})$. There were differences between plant treatments over time for total $\mathrm{NO}_{3}{ }^{-}$leached from QRF $16 \mathrm{~N}-1.7 \mathrm{P}-6.6 \mathrm{~K}$ (Table 4). Turfgrass leached less $\mathrm{NO}_{3}{ }^{-}$than ornamentals at 15 DAT and when averaged over all leaching events. There were no differences in leaching

Table 3. Nitrate leaching $\left(\mathrm{mg} \cdot \mathrm{L}^{-1}\right)$ from turfgrass and ornamentals ${ }^{\mathrm{z}}$ in response to fertilizer treatments. ${ }^{\mathrm{y}}$

\begin{tabular}{llcccc}
\hline Fertilizer & \multicolumn{1}{c}{ Plant } & Day 15 & Day 30 & Day 60 & Avg \\
\hline QRF 15N-0P-12.5K & Turf & 0.30 & 0.19 & 0.11 & 0.21 \\
& Ornamentals & 0.40 & 0.24 & 0.28 & 0.26 \\
& ANOVA & NS & NS & NS & NS \\
QRF 16N-1.7P-6.6K & Turf & 0.16 & 0.14 & 0.11 & 0.14 \\
& Ornamentals & 0.66 & 0.60 & 0.28 & 0.52 \\
& ANOVA & 0.01 & NS & 0.006 & 0.002 \\
SRF 8N-1.7P-9.9K & Turf & 0.13 & 0.10 & 0.10 & 0.11 \\
& Ornamentals & 0.28 & 0.23 & 0.17 & 0.23 \\
& ANOVA & NS & NS & NS & NS \\
\hline
\end{tabular}

${ }^{\mathrm{z}}$ Ornamentals included Canna generalis L. var. Brandywine, Ligustrum japonicum Thunb. var. Lake Tresca, Nandina domestica Thunb. var. Harbor Dwarf, and Allamanda cathartica L.

${ }^{y}$ Data are averaged over six fertilizer cycles (FC).

$\mathrm{QRF}=$ quick-release fertilizer; SRF $=$ slow-release fertilizer; ANOVA = analysis of variance; $\mathrm{NS}=$ Nonsignificant.

Table 4. Nitrate leaching (mg) from turfgrass and ornamentals ${ }^{\mathrm{z}}$ in response to fertilizer treatments. ${ }^{\mathrm{y}}$

\begin{tabular}{llcccc}
\hline Fertilizer & \multicolumn{1}{c}{ Plant } & Day 15 & Day 30 & Day 60 & Total \\
\hline QRF 15N-0P-12.5K & Turf & 2.20 & 0.90 & 0.87 & 3.97 \\
& Ornamentals & 1.85 & 0.94 & 0.61 & 3.40 \\
& ANOVA & NS & NS & NS & NS \\
QRF 16N-1.7P-6.6K & Turf & 1.10 & 0.74 & 0.76 & 2.60 \\
& Ornamentals & 2.67 & 1.95 & 1.00 & 5.62 \\
& ANOVA & 0.009 & NS & NS & 0.01 \\
SRF 8N-1.7P-9.9K & Turf & 0.84 & 0.70 & 0.68 & 1.52 \\
& Ornamentals & 1.63 & 1.21 & 1.00 & 3.84 \\
& ANOVA & NS & NS & NS & NS \\
\hline
\end{tabular}

${ }^{\mathrm{z}}$ Ornamentals included Canna generalis L. var. Brandywine, Ligustrum japonicum Thunb. var. Lake Tresca, Nandina domestica Thunb. var. Harbor Dwarf, and Allamanda cathartica L.

${ }^{y}$ Data are averaged over six fertilizer cycles (FC).

$\mathrm{QRF}=$ quick-release fertilizer; $\mathrm{SRF}=$ slow-release fertilizer; ANOVA = analysis of variance; $\mathrm{NS}=$ Nonsignificant.

between the other fertilizer treatments at any sampling date.

Leaf tissue nutrient concentration. There were no differences in leaf tissue nutrient concentration for any nutrients in turfgrass (data not shown). This implies that nutrient uptake is similar regardless of fertilizer source.

Multispectral reflectance. Optimal MSR values in the first 2-week period after treatment were obtained with either QRF treatment (Table 5). During the first 2 weeks after treatment application, QRFs released $\mathrm{N}$ faster than SRF, resulting in better turfgrass vigor and quality and greater light assimilation. The availability of $\mathrm{N}$ has an impact on total chlorophyll content, which can be detected by MSR (Carter, 1993; Carter and Miller, 1994; Trenholm et al., 2000b). At weeks 3 through 5, wavelengths 450 and $710 \mathrm{~nm}$ and Stress-1 index had better responses from QRF $15 \mathrm{~N}-$ $0 \mathrm{P}-12.5 \mathrm{~K}$ than from SRF $8 \mathrm{~N}-1.7 \mathrm{P}-9.9 \mathrm{~K}$. There were no differences in reflectance through the rest of the FC (data not shown).

\section{Conclusions}

Visual quality scores of both turfgrass and ornamentals were greater in the 2 weeks after fertilizer application with QRF than with SRF. Less biomass production (thatch and shoot weight) was observed in SRF-treated turfgrass. No difference was noticed in leaf nutrient concentration resulting from fertilizer treatments. Less $\mathrm{NO}_{3}{ }^{-}$was leached from turfgrass than from ornamentals at 15 and 30 DAT. More $\mathrm{NO}_{3}{ }^{-}$was leached from QRF $16 \mathrm{~N}-1.7 \mathrm{P}-6.6 \mathrm{~K}$ than from SRF $8 \mathrm{~N}-1.7 \mathrm{P}-9.9 \mathrm{~K}$ when averaged over both plant types and across sampling dates. Multispectral reflectance and visual results indicate that QRFs produce better quality turfgrass for the first 2 weeks after fertilizer application with no differences in visual scores observed after that.

These visual and growth data are typical of turfgrass responses to various fertilizer sources and indicate the relative predictability of turfgrass to fertilizers. Professional lawn care services have often relied on these

Table 5. Multispectral reflectance values in turfgrass throughout the fertilizer cycle (FC).

\begin{tabular}{|c|c|c|c|c|c|c|c|c|}
\hline & WV (nm) & 450 & 550 & 660 & 694 & 710 & NDVI & Stress -1 \\
\hline$\overline{0-2}$ & QRF $15 \mathrm{~N}-0 \mathrm{P}-12.5 \mathrm{~K}$ & $3.76 \mathbf{a}^{y, x}$ & $7.83 \mathrm{a}$ & 3.82 a & 5.07 a & $9.71 \mathrm{a}$ & 0.86 a & $0.24 \mathrm{a}$ \\
\hline \multirow[t]{2}{*}{ WAT } & QRF $16 \mathrm{~N}-1.7 \mathrm{P}-6.6 \mathrm{~K}$ & $3.71 \mathrm{a}^{\mathrm{z}}$ & $7.80 \mathrm{a}$ & $3.71 \mathrm{a}$ & $4.99 \mathrm{a}$ & $9.63 \mathrm{a}$ & 0.86 a & $0.24 \mathrm{a}$ \\
\hline & SRF $8 \mathrm{~N}-1.7 \mathrm{P}-9.9 \mathrm{~K}$ & $5.18 \mathrm{~b}$ & $10.33 \mathrm{~b}$ & $6.06 \mathrm{~b}$ & $7.54 \mathrm{~b}$ & $13.51 \mathrm{~b}$ & $0.79 \mathrm{~b}$ & $0.33 \mathrm{~b}$ \\
\hline ANOVA & ANOVA & 0.0002 & 0.0018 & $<0.0001$ & $<0.0001$ & $<0.0004$ & $<0.0001$ & $<0.0001$ \\
\hline $3-5$ & QRF $15 \mathrm{~N}-0 \mathrm{P}-12.5 \mathrm{~K}$ & $4.04 \mathrm{a}$ & $7.34 \mathrm{a}$ & $4.25 \mathrm{a}$ & 5.79 a & 8.67 a & 0.837 a & 0.27 a \\
\hline \multirow[t]{2}{*}{ WAT } & QRF $16 \mathrm{~N}-1.7 \mathrm{P}-6.6 \mathrm{~K}$ & $4.80 \mathrm{ab}$ & 8.79 a & $4.82 \mathrm{a}$ & $6.11 \mathrm{a}$ & $11.15 \mathrm{ab}$ & 0.832 a & $0.29 \mathrm{ab}$ \\
\hline & SRF $8 \mathrm{~N}-1.7 \mathrm{P}-9.9 \mathrm{~K}$ & $6.42 \mathrm{~b}$ & 9.89 a & $6.34 \mathrm{a}$ & 7.58 a & $12.59 \mathrm{~b}$ & 0.774 a & $0.37 \mathrm{~b}$ \\
\hline ANOVA & ANOVA & 0.08 & NS & NS & NS & 0.06 & NS & 0.03 \\
\hline
\end{tabular}

${ }^{2}$ Means followed by the same letter do not differ significantly at $P=0.05$.

${ }^{\mathrm{y}}$ Means are averaged over six fertilizer cycles.

${ }^{\mathrm{x}}$ Optimal values in bold.

$\mathrm{WAT}=$ weeks after treatment; ANOVA $=$ analysis of variance; $\mathrm{QRF}=$ quick-release fertilizer; SRF $=$ slow-release fertilizer; $\mathrm{NS}=$ nonsignificant. 
responses to provide quick green-up in lawns and achieve client satisfaction. However, environmental implications from fertilizer applications have not often been considered by professional lawn care services. These results indicate that care should be used when applying a QRF such as $16 \mathrm{~N}-1.7 \mathrm{P}-6.6 \mathrm{~K}$, but also indicate the ability of turfgrass to take up applied fertilizer. Although this research provides preliminary data on which in situ research may be modeled, further research is required to determine how nutrient release rate affects turfgrass and ornamental quality and $\mathrm{NO}_{3}^{-}$leaching in an urban landscape.

\section{Literature Cited}

Allen, S.E., C.M. Hunt, and G.L. Terman. 1971. Nitrogen release from sulfur-coated urea, as affected by coating weight, placement, and temperature. Agron. J. 63:529-533.

Brown, K.W., J.C. Thomas, and R.L. Duble. 1982. Nitrogen source effect on nitrate and ammonium leaching and run off losses from greens. Agron. J. 74:947-950.

Carter, G.A. 1993. Response of leaf spectral reflectance to plant stress. Amer. J. Bot. 80: 230-243.

Carter, G.A. and R.L. Miller. 1994. Early detection of plant stress by digital imaging within narrow stress-sensitive wavebands. Remote Sens Environ. 50:295-302.

Cisar, J.L., G.H. Snyder, and G.S. Swanson. 1992. Nitrogen, phosphorus, and potassium fertilization for histosol-grown St. Augustine grass sod. Agron. J. 84:475-479.

Erickson, J.E., J.L. Cisar, J.C. Volin, and G.H. Snyder. 2001. Comparing nitrogen runoff and leaching and between newly established St. Augustinegrass turf and an alternative residential landscape. Crop Sci. 41:18891895.

Gross, C.M., J.S. Angle, and M.S. Welterlen. 1990 Nutrient and sediment losses from turfgrass. J. Environ. Qual. 19:663-668.

Hollingsworth, B.S., E.A. Guertal, and R.H. Walker. 2005. Cultural management and nitro- gen source effects on ultradwarf Bermudagrass cultivars. Crop Sci. 45:486-493.

Killian, K.C., O.J. Attoe, and L.E. Engelbert. 1966. Urea formaldehyde as a slowly available form of nitrogen for Kentucky bluegrass. Agron. J. 58:204-206.

Petrovic, A.M. 1990. The fate of nitrogenous fertilizers applied to turfgrass. J. Environ. Qual. 19:1-14.

SAS Institute, Inc. 2003. SAS user's guide: Statistics, SAS system version 8. SAS Institute, Inc., Cary, NC

Snyder, G.H., B.J. Augustin, and J.M. Davidson. 1984. Moisture sensor-controlled irrigation for reducing $\mathrm{N}$ leaching in bermudagrass turf. Agron. J. 76:964-969.

Trenholm, L.E., J.L. Cisar, and J.B. Unruh. 2000a St. Augustinegrass for Florida lawns. Univ. of Fla. Coop. Ext. Serv., ENH 5. Univ. of Florida, Gainesville, FL.

Trenholm, L.E., M.J. Schlossberg, G. Lee, W. Parks, and S.A. Geer. 2000b. An evaluation of multispectral responses on selected turf grass species. Int. J. Remote Sens. 21:709-721. 